\title{
ANALISIS ETIKA BISNIS DAN MARKETING NABI MUHAMMAD SAW
}

\author{
Ubbadul Adzkiya' \\ Dosen Fakultas Agama Islam \\ Universitas Wahid Hasyim Semarang \\ Adzkiya24@gmail.com
}

\begin{abstract}
Abstrak
Etika bisnis yang dilakukan oleh Nabi Muhammad menjadi menarik untuk dikaji, beliau yang hidup dalam masyarakat Arab bercorak ke-jahiliyyah-an berhasil menerapkan nilai-nilai etika, sebuah kesuksesan luar biasa. Melihat latar belakang kesuksesan Nabi Muhammad dalam berbisnis, sehingga kita patut meneliti, pertama, etika bisnis yang dijalankan Nabi Muhammad. Kedua, serta dalam sektor marketing yang beliau lakukan, karena marketing merupakan ini dari sebuah bisnis. Penulis menggunakan metodologi kualitatif dengan pendekatan sejarah. Penulis mencoba menguak fakta sejarah dibalik kesuksesan Nabi Muhammad dalam berbisnis. Melalui pendekatan sejarah diharapkan dapat memberi gambaran tentang etika bisnis dan marketing yang dipraktekkan oleh Nabi Muhammad. Dengan menggunakan pendekatan sejarah telah membuktikan bahwa; pertama, Nabi Muhammad adalah pedagang sukses, proses panjang yang telah beliau jalani menjadi tuntunan bagi umat manusia untuk meneladani etika bisnis beliau dalam kehidupan sehari-harinya. Pengalamannya sebagai seorang pedagang Nabi Muhammad dapatkan jauh sebelum beliau diutus oleh Allah swt menjadi Nabi dan Rasul. Dan kemudian dari beberapa pengalaman Nabi Muhammad dilegislasikan dalam bentuk sabda setelah beliau diutus. Kedua, Dalam praktek-prakteknya beliau selalu menjunjung tinggi kemanusiaan dan tidak hanya duniawi oriented. Beliau selalu menjaga sifat jujur, ikhlas, profesional, silaturrahim dan murah hati dalam semua aktifitasnya terutama dalam bisnisnya.

Keywords: etika, bisnis, dan Muhammad
\end{abstract}

\begin{abstract}
Business ethics conducted by the Prophet Muhammad became interesting to be studied, he was living in Arab society patterned the jahiliyyah-an successfully applied ethical values. So it can reap a tremendous success. By looking at the background of the Prophet Muhammad's success in business, we should examine, firstly, the business ethics of Prophet Muhammad carried. Secondly, in the marketing sector that he did, because marketing is this form a business. The author uses a qualitative methodology with a historical approach. The author tries to uncover the historical facts behind the success of the Prophet Muhammad in business. Using the historical approach is expected to give an overview of business ethics and marketing practiced by the Prophet Muhammad. Using the historical approach has proved that; first, the Prophet Muhammad is a successful trader, the long process he has undergone as a guide for mankind to emulate his business ethics in his daily life. His experience as a trader of the Prophet Muhammad got long before he was sent by Allah swt to be Prophet and Messenger. And then from some experiences the Prophet Muhammad was legislated in the form of the word after he was sent. Secondly, In his practices he always upholds humanity and is not only worldly oriented. He always maintain the nature of honest, sincere, professional, silaturrahim and generous in all his activities, especially in business.
\end{abstract}

Keyword: etic, business and Muhammad 


\section{Pendahuluan}

Sejarah panjang dalam hidup Muhammad sebagai seorang pebisnis dalam sektor perdagangan memberikan suri teladan bagi umat manusia secara umum. Julukan al-amin yang disandang beliau merupakan bukti bahwa Muhammad orang yang sudah diakui kredibelitasnya di masyarakat Arab sebagai sosok yang luar biasa. Muhammad memang pribadi yang kompleks, selain predikatnya sebagai orang jujur beliau peroleh, ia juga sebagai seorang nabi dan rasul.

Predikat Muhammad sebagai al-amin, menjadi modal utama dan rahasia sukses beliau menjalankan aktifitas dagangnya. Tercatat dalam berbagai literatur bahwa sejak kecil Muhammad sudah terkondisikan oleh alam dan keadaan keluarga maupun masyarakat sebagai seorang pejuang. Berangkat dari kepribadian beliau maka lahirlah tuntunan atau teladan yang bisa dijadikan masyarakat di zaman sekarang untuk sebagai pelajaran.

Jujur dalam menjelaskan produk merupakan etika bisnis yang selalu dilakukannya. Kejujuran Muhammad sudah diakui, beliau adalah manusia yang paling jujur di dunia. Beliau selalu mengatakan dengan jujur produk/barang yang didagangkannya, jika barang itu rusak atau jelek, beliau akan mengatakan kerusakan atau kejelekan barang tersebut. Sangat jarang pedagang yang berani berkata jujur perihal kualitas barang dagangannya.

Untuk mempermudah pembahasan dalam analisis, penulis menggunakan standar prinsip etika bisnis yang dikemukakan oleh Sony Keraf. Beberapa prinsip yang dijadikan patokan dalam bahasan ini, yaitu pendapat Sonny Keraf. Dalam prinsip etika bisnis dia berpendapat: otonomi, kejujuran, tidak berbuat jahat, keadilan dan hormat pada diri sendiri. ${ }^{1}$

Kejujuran menjadi kunci utama dalam praktek bisnis Muhammad, kejujuran yang Muhammad praktekkan adalah dengan menyampaikan kondisi riil barang dagangannya. Diceritakan dalam suatu riwayat suatu hari ada

${ }^{1}$ Sonny Keraf, Etika Bisnis, (Yogyakarta: Kanisius, 1998), hlm. 32 
pembeli yang menanyakan kain yang pernah dibeli temannya. Lantas Muhammad menjawab, "kain yang tuan inginkan sudah habis, ini ada yang lain tetapi beda dengan yang tuan maksud, dan harganya tentu berbeda dengan yang teman tuan beli tadi." Lantas pembeli merasa kalau Muhammad hendak menaikkan harga tersebut karena sedang digandrungi oleh konsumen. Dan menurut pandangan pembeli kain tersebut sama dengan yang dibeli temannya tadi. Kemudian pembeli bertanya, "Apakah engkau akan menaikkan harga kain ini?," Muhammad menjawab "tidak, justru harga kain ini lebih murah dari yang teman anda beli, walaupun kain ini memang sama persis dengan yang teman anda beli, tapi kualitasnya berbeda." ${ }^{2}$

Dari sebuah cerita tersebut kita bisa melihat bagaimana Muhammad sangat menjunjung tinggi kejujuran. Padahal kalau beliau mau bisa menaikkan harga barang tersebut sedang menjadi tujuan konsumen yang pasti akan membelinya. Sepintas memang itu hal yang tidak lazim dalam praktek-praktek bisnis sekarang, meskipun pebisnis sebenarnya menyadari bahwa kejujuran menjadi kunci sukses dalam berbisnis, termasuk untuk mampu bertahan dalam jangka panjang di dalam persaingan.

Prinsip jujur dalam menjelaskan produk yang dipraktekkan Muhammad kalau kita tarik ke dalam prinsip etika bisnis modern samadengan prinsip etika bisnis modern yang dijelaskan oleh Sonny Keraf. Dalam prinsipnya etika bisnis memegang prinsip kejujuran. Kejujuran etika bisnis Muhammad dalam hal ini, lebih terspesifikasi dalam kejujuran yang terwujud dalam mutu barang atau jasa yang ditawarkan dalam etika bisnis modern.

Kejujuran merupakan tonggak dalam kehidupan masyarakat yang beradab. Kejujuran berarti apa yang dikatakan seseorang itu sesuai dengan hati nuraninya. Jujur dapat pula diartikan seseorang yang bersih hatinya dari perbuatan-perbuatan yang dilarang oleh agama dan hukum. Orang yang menepati janji atau menepati kesanggupan, baik yang telah terlahir dalam

\footnotetext{
${ }^{2}$ Laode Kamaludin dan Aboza M. Richmuslim, Cerdas Bisnis Cara Rasulullah, (Jakarta: Richmuslim Adikarya Bangsa, 2010), hlm. 164
} 
kata-kata maupun yang masih dalam hati dapat dikatakan jujur. Sedangkan bagi orang yang tidak menepati janji maka orang tersebut dikatakan tidak jujur. Setiap orang hendaknya dapat bersikap jujur karena kejujuran dapat mendatangkan ketenteraman hati, menghilangkan rasa takut, dan mendatangkan keadilan. ${ }^{3}$

Kalau melihat sejarah Muhammad, memang beliau pada masa itu dihadapkan pada realitas kondisi masyarakat Arab jahiliyah pada masa itu yang menanggalkan sifat jujur dalam aktifitas dagangnya. Muhammad dengan komitmennya bisa bertahan dan akhirnya menjadi kepercayaan para anak yatim dan janda kaya raya yang tidak bisa mengelola hartanya. ${ }^{4}$ Kejujuran pulalah yang menjadikan Khadijah seorang kaya raya di Makkah tertarik pada Muhammad dan akhirnya menikah dengan Muhammad. Selanjutnya yang menjadi etika bisnis Muhammad yaitu suka sama suka. Permintaan dan penawaran dalam sistem jual beli akan terasa nikmat dan indah jika dilakukan secara fair dengan konsep ikhlas, di mana kedua belah pihak yang bertransaksi melakukannya atas dasar suka sama suka.

Hal inilah yang dilakukan Muhammad, beliau tidak akan melakukan transaksi jual beli kecuali kedua belah pihak suka sama suka, sehingga beliau sebagai penjual senang dan orang lain sebagai pembeli lebih senang karena ia mendapat barang yang diinginkannya dengan ikhlas dan mudah. Praktek yang dilakukan Muhammad dengan prinsip ini, kalau dilihat secara esensial memang sesuai dengan prinsip keadilan dalam etika bisnis modern. Dimana prinsip keadilan menuntut agar kita memberikan apa yang menjadi hak seseorang di mana prestasi dibalas dengan kontra prestasi yang dianggap sama nilainya, ini berarti tidak dikehendaki adanya perlakuan yang diskriminatif. ${ }^{5}$

\footnotetext{
${ }^{3}$ Akhmad Mujahidin, Etika Bisnis Dalam Islam (Analisis Terhadap Aspek Moralitas Pelaku Bisnis) dalam Jurnal Hukum Islam. Vol. IV No. 2. Desember 2005

${ }^{4}$ Afzalurrahman, Muhammad Sebagai Seorang Pedagang, (Jakarta: Yayasan Swarna Bhumy, 2000)

${ }^{5}$ Ketut Rindjin, Etika Bisnis dan Implementasinya, (Jakarta: PT Gramedia Pustaka Utama, 2008), hlm. 5
} 
Keadilan Muhammad sudah tidak diragukan lagi di masyarakat Arab, sehingga beliau dalam etika bisnis yang dilakukannya tidak menipu takaran, ukuran dan timbangan. Muhammad sangat menghindari praktek penipuan, tentunya Muhammad selalu jujur dalam menimbang. Muhammad sudah pasti tidak diragukan lagi keadilannya, namun praktek keadilan Muhammad banyak tercatat ketika sudah berupa kebijakan. Dan ini terjadi ketika Muhammad sudah di Madinah. Tapi tidak berarti bahwa Muhammad tidak adil dalam berdagang ketika masa mudanya. Dalam setiap kebijakan ekonomi Nabi mementingkan keadilan bukan saja berlaku untuk kaum muslim tetapi juga berlaku untuk kaum lainnya di sekitar Madinah. Hal ini terbukti ketika beliau diminta untuk menetapkan harga, beliau marah dan menolaknya. Ini membuktikan bahwa beliau menyerahkan penetapan harga itu pada kekuatan pasar yang alami. ${ }^{6}$

Keadilan merupakan perlakukan yang seimbang, dalam bisnisnya Muhammad selalu menerapkan keseimbangan. Barang yang kering bisa ditukar dengan barang yang kering. Penukaran barang kering tidak boleh dengan barang yang basah. Demikian juga dalam penimbangan tersebut seseorang tidak boleh mengurangi timbangan. Dalam transaksi Muhammad menjauhi apa yang disebut dengan muzabana dan muzaqala. ${ }^{7}$

Muzabana adalah menjual kurma atau anggur segar (basah) dengan anggur atau kurma kering dengan cara menimbang. Muzabana pada dasarnya adalah menjual sesuatu yang jumlahnya, berat atau ukurannya tidak diketahui dengan sesuatu yang jumlahnya, berat atau ukurannya diketahui dengan jelas. Sedang muhaqala adalah jual beli atau penukaran antara gandum belum

\footnotetext{
${ }^{6}$ Keadilan merupakan pengakuan dan perlakuan yang seimbang antara hak dan kewajiban. Misalnya, jika kita mengakui hak hidup maka kita juga berkewajiban untuk mempertahankan hak hidup itu dengan bekerja keras tanpa merugikan orang lain karena orang lain pun memiliki hak hidup yang sama dengan kita. Dengan demikian, keadilan pada dasarnya terletak pada keseimbangan atau keharmonisan antara tuntutan hak dan pelaksanaan kewajiban. Akhmad Mujahidin,loc.cit.,

7 Muhammad Saifullah, Etika Bisnis Dalam Praktek Mal Bisnis Muhammad, Jurnal Economica, vol.1/edisi I/November 2010
} 
dipanen dengan gandum yang sudah digiling atau menyewakan tanah untuk ditukarkan dengan gandum.

Nah, praktek yang dilakukan Muhammad di pasar-pasar yang dikunjungi beliau, dia selalu menimbang berat tersebut sesuai dengan ukurannya. Dia tidak mengurangi sedikitpun, sehingga kejujuran dan ketepatannya dalam menimbang sudah tersebar di mana-mana. Jika orang membeli barang dari Muhammad mereka tidak ragu atas timbangannya. ${ }^{8}$

Pada dasarnya praktek tidak menipu takaran, ukuran dan timbangan. Sesuai dengan yang digambarkan di atas sekaligus penguat dalam analisis ini, bahwa yang dilakukan oleh Muhammad ini merupakan sebuah praktek bisnis yang mulia. Selain itu sesuai dengan prinsip kejujuran yang terdapat dalam etika bisnis modern. Muhammad dalam etika bisnisnya tidak menjelekkan bisnis orang lain. ${ }^{9}$ Menjelek-jelekan bisnis orang lain yang merupakan pesaingnya adalah tindakan pengecut. Banyak orang terjebak ke dalam tindakan yang tidak terpuji demi mendapatkan keuntungan sebanyak mungkin, misalnya dengan menjatuhkan reputasi pesaingnya dengan menjelekjelekannya.

Dalam berbisnis (berdagang), Muhammad tidak pernah menjelekjelekan dagangan milik orang lain, justru beliau selalu membantu mempromosikan pedagang lain jika barang dagangan yang ada pada dirinya tidak tersedia. Hal yang dicontohkan Muhammad seperti ini akan menghasilkan sebuah iklim persaingan yang sehat. Karena antara penjual yang satu dan yang lain tidak menjelek-jelekkan bisnis orang lain.

Tindakan Muhammad yang seperti ini sesuai dengan prinsip tidak berbuat jahat (non-maleficence) dan prinsip berbuat baik (beneficence) pada etika bisnis modern. Dimana Prinsip ini mengarahkan agar kita secara aktif dan maksimal berbuat baik atau menguntungkan orang lain, dan kalau hal itu

\footnotetext{
${ }^{8}$ Ibid.,

${ }^{9}$ Amirulloh Syarbini dan J. Haryadi, Muhammad Bisnisman Ulung, (Jakarta: Elex Media Komputindo, 2011), hlm. 98
} 
tidak dapat kita lakukan minimal kita tidak merugikan orang lain. Bersih dari unsur riba, ini hal yang selalu Muhammad dalam berbisnis tidak pernah melakukan riba sedikit pun, apalagi memakan hasil riba. Bahkan dalam suatu hadits beliau mengutuk praktek riba dan menyamakan pelaku riba sebagai pembuat dosa besar.

Pada dasarnya, menengok dalam perilaku Muhammad yang seperti ini sebenarnya bisa dengan prinsip tidak berbuat jahat (non-maleficence) dan prinsip berbuat baik (beneficence). Dimana Prinsip ini mengarahkan agar kita secara aktif dan maksimal berbuat baik atau menguntungkan orang lain. Praktek ini disamakan karena pada kenyataannya dan hukumnya riba merupakan perilaku yang jahat dan merugikan terhadap orang lain. ${ }^{10}$

Tidak menimbun barang Dalam bahasa Arab disebut dengan "alikhtikar". Kata ini mengandung makna azh-zhulm (aniaya) dan isa'ah almu'asyirah (merusak pergaulan). Secara umum dapat diambil pengertian yaitu aktivitas menyimpan barang yang dibutuhkan masyarakat dengan tujuan menjualnya ketika harga telah melonjak, barang itu baru dipasarkan. Muhammad dalam berbisnis tidak pernah melakukan penimbunan barang, bahkan beliau melarang para pedagang melakukan penimbunan. Hal ini tercermin dalam berbagai hadits yang ditegaskan beliau tentang larangan dan ancaman bagi orang yang menimbun. Ketika berbisnis dengan Khadijah Muhammad selalu menjual barang dagangannya sampai habis. Namun karena keterbatasan alat transportasi Muhammad membawa barang dagangan secukupnya. Penimbunan barang menjadi tradisi orang-orang jahiliyah, ini mereka jadikan strategi untuk mendapatkan keuntungan yang besar. ${ }^{11}$

\footnotetext{
${ }^{10}$ Ketut Rindjin, loc.cit., , h. 76-77

11 Dalam bahasa Arab istilah penimbunan disebut dengan ikhtikar, adalah tindakan menyimpan harta, manfaat atau jasa dan enggan menjual dan memberikannya kepada orang lain yang berakibat melonjaknya harga pasar secara drastis disebabkan persediaan terbatas atau stok barang hilang sama sekal dari pasar. Sementara masyarakat amat membutuhkan produk, manfaat atau jasa tersebut. Amirulloh Syarbini dan J. Haryadi, Muhammad Bisnisman Ulung, Jakarta: Elex Media Komputindo, 2011, hlm. 102-103
} 
Konsep tidak menimbun barang tersebut sesuai dengan prinsip kejujuran dalam etika bisnis modern. Karena dengan kita menimbun suatu barang berarti kita tidak jujur terhadap pembeli, selain itu tindakan menimbun juga membuat kekacauan dalam harga dan perekonomian pasar. ${ }^{12}$ Muhammad tidak pernah melakukan tindakan ataupun praktek seperti itu. Monopoli perdagangan merupakan kebiasaan masyarakat Arab dalam berdagang, ini terjadi karena persaingan antar suku yang begitu dominan. Sehingga persaingan dagang dengan cara saling memonopoli menjadi hal yang biasa di Arab. Dalam perilaku dagangnya muhammad tidak melakukan monopoli, monopoli merupakan cara batil dalam memperoleh harta.

Sebab praktek monopoli pada umumnya merugikan orang lain karena bersifat tidak fair dan tidak memberikan kesempatan kepada orang lain untuk bisa melakukan usaha yang sama. Sehingga bisa dikatakan kegiatan monopoli adalah sebuah tindakan yang jahat. Maka dari itu Muhammad tidak pernah mempraktekkannya. Prinsip ini ternyata sama dengan prinsip tidak berbuat jahat (non-maleficence) dan prinsip berbuat baik (beneficence) pada etika bisnis modern. Selanjutnya, dalam berbisnis Muhammad berpegang pada sifat amanah. Amanah merupakan tanggung jawab moral yang dibebankan kepada setiap orang, baik dalam melaksanakan tugas penghambaan kepada Tuhannya maupun tugas kemanusiaan antar sesamanya. Dalam menjalankan aktifitas bisnisnya Muhammad menggunakan sifat amanah sebagai prinsip, ketika beliau masih menjadi karyawan Khadijah, ia memperoleh kepercayaan penuh membawa barang-barang dagangan Khadijah untuk dibawa dan dijual di Syam. Dengan ditemani Maesaroh Muhammad menjual barang dagangannya sesuai dengan yang diamanatkan Khadijah. ${ }^{13}$

\footnotetext{
${ }^{12}$ Ketut Rindjin, op.cit., , hlm. 76-77

${ }^{13}$ M. Saifullah, loc.cit., Amanah dalam perspektif agama Islam memiliki makna dan kandungan yang luas, di mana seluruh makna dan kandungan tersebut bermuara pada satu pengertian yaitu setiap orang merasakan bahwa Allah swt senantiasa menyertainya dalam setiap urusan yang dibebani kepadanya, dan setiap orang memahami dengan penuh keyakinan bahwa kelak ia akan dimintakan pertanggungjawaban atas urusan tersebut. Lebih lengkap mengenai amanah lihat dalam H. Ali Fikri Noor, Lc, MA, Amanah, http://www.alhikmah.ac.id/ Artikel/Akhlaq/Amanah.pdf. diunduh pada 28 November 2011
} 
Muhammad sangat menjaga kepercayaan dalam berdagang, tidak hanya kepercayaan dari pemilik barang namun juga pelanggan dan orangorang yang terkait dengan bisnis tersebut. Dengan memegang sifat ini Muhammad mendapat simpati dari para konsumen sehingga mereka dengan suka rela melakukan transaksi dagang. Praktek ini juga sesuai dengan prinsip kejujuran dalam etika bisnis modern. Di mana prinsip kejujuran dalam etika bisnis modern mewujud dalam pemenuhan syarat-syarat perjanjian atau kontrak. Selain itu, juga bisa dipotret dengan prinsip otonomi dalam etika bisnis, karena dalam otonomi juga mengandalkan adanya tanggung jawab. Itulah sebabnya seseorang bisa diminta pertanggungjawaban atas tindakan yang telah dilakukan. ${ }^{14}$

Muhammad dalam berbisnis sangat menjunjung sifat toleran. Sifat toleran merupakan salah satu kunci sukses Muhammad. Sifat ini akan membuka kunci rezeki dan sarana hidup tenang bagi para pebisnis. Manfaat toleran adalah mempermudah pergaulan, mempermudah urusan jual beli dan mempercepat kembalinya modal. Toleran dalam berbisnis berarti sikap memudahkan dan berlapang dada dalam menjalin kerjasama bisnis, baik perdagangan, industri maupun bisnis lainnya. Sikap toleran mendorong kokohnya jalinan kemitraan bisnis, memudahkan setiap urusan, rasa empati terhadap rekan kerja dan sikap positif lainnya.

Praktek yang dilakukan Muhammad ini sesuai dengan prinsip hormat pada diri sendiri pada etika bisnis modern. Di mana seseorang bersikap toleran terhadap orang lain berarti dia menghargai orang lain seperti menghargai diri sendiri. $^{15}$

Menurut penulis, terjadi kesamaan dalam sebab musabab munculnya standar norma antara yang dilakukan Muhammad dengan yang muncul di abad modern. Hanya saja, dalam prinsip etika bisnis yang dilakukan Muhammad tidak terumuskan secara bagus sebagaimana dalam etika bisnis

\footnotetext{
${ }^{14}$ Ketut Rindjin, op.cit., hlm. 76-77

${ }^{15}$ Ketut Rindjin,Etika Bisnis... hlm. 76-77
} 
modern, yang dalam hal ini penulis menggunakan apa yang telah dikemukakan Sony Keraf.

Namun perkembangan yang terjadi sekarang, masyarakat dunia sudah dihadapkan pada keresahan-keresahan akan mulai ditanggalkannya etika dalam urusan bisnis, sehingga berangkat dari latar belakang tersebut para ilmuwan barat merumuskan beberapa standar atau pedoman. Pada penelitian ini penulis jadikan potret terhadap praktek bisnis yang dilakukan Muhammad 14 abad sebelumnya. Perlu penulis tegaskan bahwa penelitian ini fokus pada praktek yang dilakukan Muhammad sebelum diutus resmi menjadi Rasul. Sehingga justifikasi ajaran Islam bisa saja diakui atau tidak, tergantung bagaimana orang memandang status Muhammad qoblal bi'tsah. Hemat penulis, paling tidak praktek-praktek bisnis Muhammad sebelum diutus bisa menjadi pelajaran tersendiri bagi masyarakat bagaimana beliau dengan prakteknya yang mulia itu bisa meraih kesuksesan.

Etika bisnis yang dibawa Muhammad merupakan pengalaman panjang beliau, sebelum nabi diutus menjadi rasul dia sudah menjalankan banyak kegiatan dagang. Kejujuran beliau menjadi salah satu kunci sukses keberhasilannya sebagai seorang pebisnis profesional yang diakui oleh masyarakat Arab pada masa itu. Akan tetapi, apakah hanya dengan modal jujur cukup untuk bisa mengantarkan Muhammad menjadi bisnis ulung. Dalam penelitiannya M. Saifullah menjelaskan bahwa kejujuran tidak bisa menjadi modal utama dalam pengelolaan bisnisnya jika tidak didukung oleh latar belakang yang kuat yang membentuk karakter entrepreneur. ${ }^{16}$

Lebih lanjut ia menerangkan bahwa kunci sukses bisnis Muhammad adalah karena bentukan dari keluarga dan lingkungannya. Paling tidak ada empat faktor yang mempengaruhi kesuksesan Muhammad menjadi seorang pebisnis. Pertama, faktor geografis Arab, sebagaimana sudah penulis tuliskan dalam bab sebelumnya bahwa Arab adalah tanah yang tandus, yang secara

\footnotetext{
${ }^{16}$ Muhammad Saifullah, loc.cit.,
} 
ideal tidak cocok untuk sebuah kehidupan, sehingga perdagangan menjadi sumber ekonomi utama bagi masyarakat Arab. Kedua, faktor ekonomi, Muhammad memang berasal dari keluarga kaya, namun ketika Muhammad lahir dan masa kanak-kanak keadaan keluarga Muhammad tidak dalam keadaan mencukupi, sehingga Muhammad mengambil langkah kreatif mencari nafkah sendiri untuk memenuhi kebutuhannya. Ketiga, faktor keluarga, jika dirunut dari kakeknya, Muhammad berasal dari keluarga yang kaya raya, ia memiliki jabatan tinggi sebagai pembesar kaum Quraisy. Ketika terjadi perampokan binatang ternak oleh tentara Abrahah, Abdul Mutholib menemui Abrahah di perkemahan. Abrahah turun tahtanya dan menjabat tangan serta mempersilakan duduk di sebelahnya. Kebesaran Abdul Mutholib diakui Abrahah sehingga ia menghormatinya. ${ }^{17}$ Namun Muhammad tidak bangga dengan kebesaran keluarganya, pelajaran dagang sudah beliau dapatkan ketika ia mulai menggembala kambing dan kemudian turut serta bersama pamannya melakukan perjalanan dagang ke Syam. Keempat, faktor beristri Khadijah, pernikahan Muhammad dengan Khadijah merupakan pasangan yang sangat cocok. Muhammad yang dikenal sebagai pribadi yang ulet serta kejujurannya dan Khadijah sebagai janda kaya raya. Dengan pernikahan tersebut Muhammad harus bekerja keras untuk menjalankan kekayaan yang dimiliki istrinya, dan Muhammad berperan sebagai seorang manajer yang profesional. ${ }^{18}$

Pemaparan di atas dapat kita pahami bahwa Muhammad menjadi pebisnis yang sukses dan terkenal, tidak hanya faktor kepribadian beliau. Namun juga karena faktor bentukan dari lingkungan dan kondisi sosial kemasyarakatan bangsa Arab. Tentunya, Muhammad sebagai teladan membawa contoh atau perilaku yang mulia bagi umat manusia. Kejujuran yang menjadi salah satu dasar etika bisnis yang membawa kesuksesan Muhammad. Sehingga kita bisa melihat prinsip-prinsip yang dilakukan Muhammad dalam aktifitas dagangnya. Pengalaman beliau ketika muda

\footnotetext{
${ }^{17}$ Muhammad Saifullah, Amanah ...

${ }^{18}$ Muhammad Saifullah, Amanah...
} 
menjadi dasar Muhammad dalam dalam mengajarkan bagaimana bisnis yang benar dan sesuai dengan yang dikehendaki.

\section{Pembahasan}

Ujung tombak dari sebuah usaha adalah konsep marketing yang jitu, Muhammad sudah barang tentu menerapkan konsep marketing yang luar biasa hingga ia begitu populer dan dipercaya di masyarakat. Kalau kita lihat, itu adalah bagian dari konsep Muhammad dalam melakukan aktifitasnya. Jujur merupakan pengaruh yang luar biasa dalam aktifitas pemasaran Muhammad, ini merupakan brand yang bisa membuat para konsumen terharu. Dan sifat fathanah Muhammad menurut Afzalurrahman kaitannya dengan strategi pemasaran merupakan upaya membangun citra dari teladan Muhammad. Hal itu meliputi penampilan, pelayanan, persuasi dan pemuasan. ${ }^{19}$ Penampilan bagi Muhammad adalah penampilan yang tidak membohongi pelanggan, baik menyangkut besaran (kuantitas) maupun kualitas.

Pelayanan yang baik bagi beliau adalah jika ada pelanggan yang tidak sanggup membayar kontan hendaknya diberi tempo untuk melunasinya. Selanjutnya, pengampunan (bila memungkinkan) hendaknya diberikan jika ia benar-benar tidak sanggup membayarnya. Persuasi dengan bagaimana ia menjauhi sumpah yang berlebihan dalam menjual suatu barang. Dan Pemuasan, hanya dengan kesempatan bersama, dengan suatu usulan dan penerimaan, penjualan akan sempurna. ${ }^{20}$

Dalam melakukan pemasaran Muhammad benar-benar menguasai sasarannya, yaitu bagaimana ia bisa menguasai benak konsumen. Oleh karena itu penulis mencoba memotret konsep pemasaran secara umum yang

\footnotetext{
${ }^{19}$ http://cintaumiku.blogspot.com/2010/02/nilai-nilai-perilaku-bisnis-rasulullah. diakses pada 29 November 2010

${ }^{20}$ Ibid.,
} 
dilakukan Muhammad dengan kaca mata konsep marketing pada umumnya. Diantaranya dengan mind share, market share, dan heart share ${ }^{21}$

Sebagai bisnisman ulung, ${ }^{22}$ Muhammad memahami betul bagaimana ia harus menancapkan dalam-dalam di otak konsumen akan produknya. Inilah yang tercakup dalam mind share, bagaimana kita ingin diingat di hati konsumen. Hal ini tercakup dalam sebuah strategi yang di dalamnya terdapat proses segmenting, targeting, dan positioning. Segmentasi dalam pemasaran adalah cara membagi pasar berdasarkan pada variabel-variabel tertentu seperti faktor geografi, demografi, perilaku dan akhirnya variabel terkecil yaitu individu. Segmentasi yang berkesinambungan menjadi penting bagi sebuah perusahaan untuk dapat memenuhi kebutuhan (need) dan keinginan (want) pasar yang selalu berubah-ubah. ${ }^{23}$

Proses segmentasi dilakukan Muhammad sebelum ia melakukan bisnis, Muhammad melakukan kunjungan dalam rangka proses Bisnis ke Bahrain yang terletak di salah satu bagian timur Semenanjung Arabia, dikisahkan seseorang yang bernama Abdul Qais datang menemui Rasulullah SAW. Singkat kata, dalam pertemuan itu beliau meminta Abdul Qais untuk memanggil dan memberitahukan mereka yang bernama Al-Ashajj. Ketika AlAshajj menghadap, Rasulullah SAW mengajukan berbagai macam pertanyaan tentang penduduk dan berbagai urusan mereka mulai dari cara makan dan minum, dan sebagainya. Secara khusus, beliau menyebutkan nama-nama Sofa, Mushaqqar, Hijar (menurut geografi kuno, ketiga kota ini berada di Bahrain). Al-Ashajj sangat terkesan dengan pengetahuan luas yang dimiliki oleh Rasulullah SAW tentang negeri tersebut. Sehingga Al-Ashajj mengatakan, "Ayah dan Ibuku akan berkorban demi Anda karena Anda lebih tahu banyak tentang negeriku dibanding aku sendiri dan anda mengetahui nama-nama kota lebih banyak di negeri kami daripada yang kami ketahui”. Dan Rasulullah

${ }^{21}$ Thorik Gunara dan utus Hardiono Sudibyo, Marketing Muhammad saw, Bandung: Madania Prima, 2008, hlm. 8

${ }^{22}$ Amirulloh Syarbini dan J. Haryadi, Muhammad Bisnisman Ulung, Jakarta: Elex Media Komputindo, 2011

${ }^{23}$ Loc.cit., hlm. 16-17 
SAW pun berkata, "Saya memiliki banyak kesempatan untuk melakukan perjalanan di negeri Anda dan di sana saya menemukan keramahtamahan yang sangat besar terhadap saya". ${ }^{24}$

Melihat dari kisah di atas jelaslah bahwa Muhammad telah melakukan proses segmentasi pasar berdasarkan faktor geografis, demografis dan psikologis. Pasar inilah yang kemudian Muhammad bidik. Berangkat dari pengetahuan yang cermat dan teliti, Muhammad dapat menjual barang dagangannya dengan baik dan mampu meraih keuntungan lebih banyak dibandingkan dengan pedagang yang lain. Selanjutnya, adalah bagaimana Muhammad melakukan targeting, ini merupakan proses pemilihan target dan mencocokkan reaksi pasar dengan kebutuhan dasar, kemampuan daya beli dan keterbatasan yang dimiliki. Pada hakikatnya targeting adalah menentukan segmen-segmen pasar yang potensial bagi perusahaan. Namun sebelumnya pengusaha harus memetakan atau menyegmentasi pasar secara kreatif, sehingga dengan begitu kita akan benar-benar mengenal potensi segmen pasar yang akan menjadi target perusahaan. ${ }^{25}$

Muhammad secara individu mampu melakukan targeting yang luar biasa, beliau tidak hanya terfokus pada satu komunitas. Namun beliau mampu memasuki semua segmen yang ada dalam masyarakat semenanjung Arab. ${ }^{26}$ Dipilihnya Makkah sebagai tempat Muhammad dilahirkan bukan tanpa alasan, bangsa Arab tidak sebiadab yang banyak digambarkan oleh para sejarawan. Mereka sudah mempunyai peradaban yang cerdas dan daya tangkap terhadap realitas alam yang terjadi di sekitarnya. ${ }^{27}$ Secara geografis, semenanjung Arab merupakan tempat yang dikelilingi benteng-benteng alam yang dapat menjaga mereka dari serangan orang-orang barbar. Jazirah Arab terletak di tengah-

\footnotetext{
${ }^{24} \mathrm{http} / / /$ pengusaharindusyariah.com/segmentasi-untuk-penetrasi-serial-mind-share-1/

${ }^{25}$ Hermawan Kartajaya, Hermawan Kartajaya On Targeting, seri 9 Elemen Marketing, Bandung; Mizan, 2006, hlm. 14

${ }^{26}$ Loc.cit., hlm. 21

${ }^{27}$ Khalil Abdul Karim, Syari'ah, Sejarah Perkelahian Pemaknaan, Yogyakarta: LKiS, 2003
} 
tengah peradaban dan kebudayaan Persia dan Romawi yang pada masa itu menjadi negara adidaya. ${ }^{28}$

Muhammad mampu menjadi sosok yang disegani kalangan pengusaha Arab, semua ucapan dan perbuatannya selalu diteladani dan dijadikan contoh bagi orang lain. Muhammad telah melakukan targeting tidak hanya secara bisnis tetapi juga secara personal. Sekarang kita masuk pada positioning, positioning dalam definisi tradisional sering disebut sebagai strategi untuk memenangi dan menguasai benak pelanggan melalui produk yang kita tawarkan. ${ }^{29}$ Hermawan Kertajaya mendefinisikannya the strategy to lead your customer credibly, yaitu upaya mengarahkan pelanggan anda secara kredibel. ${ }^{30}$ Dapat diartikan pula bahwa positioning adalah bagaimana agar pelanggan kita mengingat produk atau jasa yang kita tawarkan.

Bagaimana membuat produk yang kita jual mendapatkan gelar “persepsi akan satu kategori tertentu?" persepsi sangat menentukan kekuatan sebuah produk dalam benak customer, ketepatan dalam melakukan positioning sangat diperlukan untuk menciptakan paradigma perception is reality.

Mari kita lihat Muhammad, dalam melakukan positioning Muhammad lebih condong pada pembentukan branding pada dirinya. Ini dikarenakan pada masa itu positioning bukan pada produk makanya merek belum digunakan seperti yang lazim dilakukan sekarang. Sosok kejujuran kembali menjadi positioning Muhammad. Beliau tidak pernah memberikan kesempatan pelanggan untuk mengeluh, ia selalu menepati janji dan mengantar barangbarang yang kualitasnya telah disepakati oleh kedua belah tepat pada waktunya. $^{31}$

\footnotetext{
${ }^{28}$ Lebih lengkap tentang sejarah Arab dalam, Philip K. Hitti, History oh The Arabs, Jakarta: PT Serambi Ilmu Semesta, 2010,

${ }^{29}$ Hermawan Kartajaya, Hermawan Kartajaya On Positioning, Seri 9 Elemen Marketing, Bandung; Mizan, 2006, hlm. 13

${ }^{30}$ Ibid.,

${ }^{31}$ Loc.cit., hlm. 29
} 
Reputasi Muhammad sebagai pedagang yang jujur dan terpercaya telah terbina dengan baik sejak usia muda, baik di kalangan pengusaha maupun di kalangan pemodal yang merupakan orang-orang kaya di Makkah. Beliau selalu memperlihatkan rasa tanggung jawab dan integritas yang besar dalam berurusan dengan orang lain, ini bisa dilihat dari sejarah dagang Muhammad sehingga ia pun bisa dipercaya oleh anak-anak yatim dan janda-janda kaya di Makkah termasuk Khadijah salah satunya untuk menjalankan dagangannya. ${ }^{32}$ Positioning itulah yang secara terus menerus beliau tanamkan sehingga mengakar dengan baik dalam benak para pengusaha.

Muhammad juga membangun positioning dalam kehidupan sehari-hari hingga dijadikan sebagai identitas dan image bagi orang yang belum mengenalnya. Maka tidak heran jika beliau diidolakan, dikagumi dan diikuti banyak orang atas semua tindak tanduk yang beliau lakukan. Konsep pemasaran selanjutnya adalah market share atau pangsa pasar, yaitu, persentase dari keseluruhan pasar untuk sebuah kategori produk atau service tertentu yang dikeluarkan sebuah perusahaan dalam kategori yang sama. Untuk menguasai pangsa pasar tertentu setiap perusahaan mempunyai strategi yang berbeda-beda. Taktik utama yang digunakan untuk merebut pangsa pasar adalah dengan diferensiasi, bauran pemasaran (marketing mix) dan selling. ${ }^{33}$

Hermawan Kartajaya mendefinisikan diferensiasi berbeda dengan pengertian pada umumnya, dia mendefinisikan diferensiasi sebagai upaya mengintegrasikan sesuatu yang disebut konten, konteks, dan infrastruktur dan layanan yang kita tawarkan kepada pelanggan. ${ }^{34}$ Salah satu yang ditempuh untuk mendapatkan diferensiasi adalah dengan mengintegrasikan konten, konteks dan infrastruktur yang kita miliki sehingga dapat menjadi nilai lebih yang dapat kita tawarkan kepada pelanggan. Esensinya adalah agar lebih dikenal sehingga menjadi identitas diri. Kondisi jazirah Arab yang tandus dan

\footnotetext{
${ }^{32}$ Afzalurrahman, juga sudah dibahas pada bab sebelumnya tentang sejarah perekonomian Muhammad.

${ }^{33}$ Op.cit., hlm. 33-34

${ }^{34}$ Hermawan Kartajaya, Hermawan Kartajaya On Differentiation, The 9 Core Element Of Marketing Series, Bandung: Mizan, 2006, hlm. 14
} 
dikelilingi padang pasir, tidak memungkinkan adanya air yang meruah limpah. Hanya beberapa kota di Hijaz yang sering turun hujan. Perdagangan yang dilakukan Muhammad sudah merupakan diferensiasi dalam memilih aktifitas untuk memenuhi kebutuhan hidupnya. Sudah pasti Muhammad tahu bahwa jazirah Arab sangat cocok untuk melakukan aktifitas bisnis, selain kondisi geografis juga faktor alam yang tidak begitu tepat untuk bercocok tanam.

Secara personal Muhammad telah menciptakan diferensiasi tersendiri. Keuntungan berlipat ganda yang sering Muhammad peroleh menjadikan reputasi Muhammad melesat naik sebagai satu-satunya pedagang muda yang luar biasa di Arab. Cara berdagangan Muhammad tidak lantas menjadikan beliau diasingkan tapi malah dijadikan sebagai kesempatan untuk menjalin kerjasama dengan pedagang lain di Arab. Istilahnya Sam Hill dan Glenn Rifkin sebagaimana dikemukakan Tharik Gunawan, terobosan-terobosan bisnis yang dilakukan Muhammad dapat disebut sebagai radikal marketing. Radikal di sini bukan dalam artian yang negatif atau bahkan destruktif. Radikal yang dimaksud adalah berbeda dan perbedaan tersebut bisa menjadi solusi bagi permasalahan yang sering timbul pada pola perdagangan konvensional pada masa itu. ${ }^{35}$

Selanjutnya ada yang namanya marketing mix $^{36}$ (bauran pemasaran) dalam strategi perebutan pangsa pasar. Penggunaan konsep marketing mix sudah dianggap sebagai sebuah keharusan dalam pemasaran, sebenarnya marketing mix hanya sebatas elemen dari taktik dalam pemasaran. Marketing mix secara terperinci terdiri atas product, price, place dan promotion. ${ }^{37}$ Konsep yang pertama adalah product, Muhammad selalu menjelaskan dengan baik kepada semua pembelinya akan kelebihan dan kekurangan produk yang ia

\footnotetext{
${ }^{35}$ Op.cit,hlm., 44

${ }^{36}$ Jika berbicara marketing mix pasti kita diingatkan pada Jerome McCarthy, dialah yang dikenal sebagai "Bapak" marketing mix, berkat beliau konsep 4P dikenal masyarakat dan sering dijadikan rujukan ketika membahas tentang pemasaran. Hermawan Kartajaya, Hermawan Kartajaya On Marketing Mix, The 9 Core Element Of Marketing Series, Bandung: Mizan, 2006, hlm. 17

${ }^{37}$ Ibid., hlm. 18
} 
jual. Kejujuran memegang peranan penting dalam perniagaan Muhammad, kejujuran adalah cara yang paling murah walau dirasakan sangat sulit dan telah menjadi barang yang sangat langka. Dengan jujur pada konsumen mengenai baik dan buruknya atau kekurangan dan kelebihan suatu produk akan membuat konsumen percaya pada kita. Price, tidak diperbolehkannya pembatasan harga komoditi di masa Muhammad merupakan cerminan pemikiran yang mewakili konsep pricing, Muhammad bersabda, "janganlah kamu menjual menyaingi penjualan saudaramu". Konsep persaingan yang sehat sudah ditekankan oleh Muhammad. Perang harga (the war of price) tidak diperkenankan karena bisa menjadi bumerang bagi para penjual. Secara tidak langsung Muhammad menyuruh kita untuk tidak bersaing di harga, tetapi bersaing dalam hal lain seperti quality (kualitas), delivery (layanan) dan value added (nilai tambah). ${ }^{38}$ Place, berarti lokasi dan distribusi. Pada masa Muhammad telah ada kecenderungan orang-orang untuk memotong jalur distribusi. Muhammad melarang menyongsong (mencegat) pedagang sebelum tiba di pasar, dan melarang orang kota membeli dagangan orang desa, inti dari pelarangan tersebut adalah untuk menghindari adanya tengkulak (perantara). Bagi Muhammad transaksi yang baik adalah transaksi yang di dalamnya tidak ada pihak yang dirugikan dan saling menguntungkan. ${ }^{39}$ Promotion, dalam menjual Muhammad tidak pernah melebih-lebihkan produk dengan maksud untuk memikat pembeli. Muhammad dengan tegas menyatakan bahwa seorang penjual harus menjauhkan diri dari sumpah-sumpah yang berlebihan dalam menjual suatu barang. Muhammad tidak pernah melakukan sumpah untuk melariskan dagangannya, kalaupun ada yang bersumpah, Muhammad menyarankan orang itu untuk tidak melakukan sumpah tersebut terlalu berlebihan. ${ }^{40}$

Taktik selanjutnya setelah diferensiasi dan marketing mix adalah selling, bahasa yang paling sederhana adalah menjual, menjual salah satu

\footnotetext{
${ }^{38}$ Ibid., hlm. 61

${ }^{39}$ Ibid., hlm. 62

${ }^{40}$ Ibid., hlm. 57
} 
proses tersulit yang harus dijalani oleh sebuah perusahaan. Dalam istilah yang lebih dalam selling adalah bagaimana menciptakan hubungan jangka panjang dengan pelanggan melalui produk atau jasa perusahaan anda, dalam hal ini selling berarti sebuah taktik yang dapat mengintegrasikan pelanggan, perusahaan dan relasi antar keduanya. ${ }^{41}$ Selling yang dilakukan Muhammad tidak sekadar menjual produk demi mengeruk keuntungan secara finansial, tapi lebih pada kenyamanan bertransaksi dan pelayanan yang diberikan saat bertransaksi. Etika dalam berbisnis menjadi hal yang paling utama untuk seorang Muhammad.

Beliau sangat menghormati hak-hak individu dalam berdagang, dari pihak perdagangan maupun dari pihak pembeli. Dalam prinsipnya perdagangannya, Muhammad tidak memberikan keistemewaan kepada pihak yang satu atas pihak yang lain. Tahap selanjutnya dalam marketing setelah menaklukkan mind share dan market share adalah heart share. Dalam heart share yang perlu diperhatikan adalah brand, process, dan service.

Brand, sebuah nama, istilah, simbol ataupun hal lain yang dapat menjadi sebuah identitas dari sebuah produk atau jasa. Brand is everything kata Hermawan Kartajaya, merek adalah indikator value yang anda tawarkan kepada pelanggan. Merek merupakan aset yang menciptakan value bagi pelanggan dengan memperkuat kepuasan dan loyalitasnya. Dan menjadi alat ukur bagi kualitas value yang anda tawarkan. ${ }^{42}$

Sejarah Muhammad sebagai seorang pedagang sukses merupakan brand yang luar biasa. Ketika mulai dewasa dan beranjak muda Muhammad sudah dikenal para pedagang dan pemilik modal di Arab. Pengalaman beliau melanglang kemana-mana menjadikan Muhammad orang yang disegani di Makkah, usia mudanya sudah dihabiskan untuk perjalanan dagang ke berbagai negeri tetangga. Dan pada akhirnya dia dipercaya janda kaya raya, Khadijah,

\footnotetext{
${ }^{41}$ Hermawan Kartajaya, Hermawan Kartajaya On Selling, The 9 Core Element Of Marketing Series, Bandung: Mizan, 2006, hlm. 17

${ }_{42}$ Hermawan Kartajaya, Hermawan Kartajaya on Branding, The 9 Core Element Of Marketing Series, Bandung: Mizan, 2006, hlm. 13
} 
untuk membawa barang dagangannya. Jelas bahwa Muhammad telah mencetak personal branding yang kuat sebagai Pengusaha yang profesional dan jujur.

Selanjutnya, process. Dapat didefinisikan sebagai penganalisaan peluang pasar, pengembangan strategi marketing, perencanaan langkahlangkah marketing yang akan dilakukan dan memaksimalkan marketing berdasarkan langkah di atas. Dalam konsep pemasaran proses mencerminkan kualitas (quality), biaya (cost) dan penghantaran produk (delivery) dari perusahaan kepada pelanggannya. ${ }^{43}$

Muhammad menjadi seorang pedagang berawal dari nol. Pada mulanya ia menjadi agen untuk beberapa pengusaha kaya di kota Makkah, dengan kegiatan Muhammad dapat mengetahui lokasi-lokasi perdagangan di mana tempat membeli dan di mana tempat menjual di daerah jazirah Arab. Ditambah dengan pengetahuan yang rinci mengenai kebiasaan penduduk setempat membuat Muhammad dapat melakukan proses perdagangan yang baik. $^{44}$

Saib bin Ali dalam buku Muhammad sang Pedagang sebagaimana ditulis Tharik Gunawa menceritakan pengalaman berdagang dengan Muhammad, ia mengatakan bahwa Muhammad selalu lurus dalam setiap perhitungannya. ${ }^{45}$ Proses panjang yang dijalani Muhammad, selalu disertai dan mempertahankan kejujuran yang ia miliki. Sehingga wajar kalau dia menjadi orang yang sukses karena ia setia dengan proses. Service, adalah hal mendasar yang dijual oleh para pengusaha baik itu pengusaha barang, terlebih lagi pengusaha jasa sehingga dapat dikatakan bahwa dasar dari setiap bisnis adalah service. Perusahaan harus dapat memberikan solusi nyata bagi

\footnotetext{
43 Ibid, hlm. 17

${ }^{44}$ Loc. cit., hlm. 82

${ }^{45}$ Ibid.,
} 
kebutuhan pelanggan. Perusahaan juga harus sensitif mendeteksi permasalahan dan kebutuhan pelanggan. ${ }^{46}$

Image Muhammad sebagai orang yang ramah dan baik sudah mewarnai dalam kehidupan sehari-harinya. Beliau sangat menghargai pelanggannya sebagaimana ia menghargai dirinya sendiri. Ini merupakan cara yang paling efektif sesuai yang diterangkan di atas dalam mempertahankan konsumen, sehingga yang terjadi hubungan yang baik antara pengusaha dan konsumen, dan pada akhirnya tercipta loyalitas konsumen.

Paradigma pembeli sebagai raja sering disalahgunakan oleh pembeli untuk berlaku seenaknya sendiri, Muhammad dalam service nya tidak hanya pada saat ia menjual tapi juga saat beliau menjadi pembeli. Dalam istilahnya Thorik Gunawan dan penulis juga mengamini, bahwa kunci dari seluruh marketing Muhammad adalah kejujuran, keikhlasan, silaturahim dan bermurah hati. Kejujuran Muhammad adalah konsep utama dari lima konsep dagang yang digunakan Muhammad. Kejujuran yang diiringi dengan konsep ikhlas sebagai konsep yang kedua akan membentuk pribadi seorang marketer atau perusahaan tidak lagi memandang materi sebagai tujuan utama. Kedua konsep tersebut kemudian dibingkai dalam sikap profesionalisme, dengan selalu berusaha secara maksimal dalam mengerjakan sesuatu atau ketika menghadapi masalah. Tidak mudah menyerah dan putus asa atau bahkan lari dari tanggung jawab. Silaturahmi sebagai konsep keempat menjadi dasar pergerakan Muhammad dalam membina hubungan baik tidak hanya dengan investor dan pelanggannya, tetapi juga terhadap calon pelanggannya bahkan dengan kompetitornya. Konsep murah hari menjadi kunci terakhir, murah hati dalam menjual dan membeli merupakan kegiatan yang dilakukan Muhammad dalam kesehariannya.

\footnotetext{
${ }^{46}$ Hermawan Kartajaya, Hermawan Kartajaya On Service, The 9 Core Element Of Marketing Series, Bandung: Mizan, 2006, hlm. 17
} 


\section{Kesimpulan}

Kesuksesan Nabi Muhammad dalam berbisnis, patut dijadikan panutan bagi pebisnis sukses manapun. Dengan menggunakan pendekatan sejarah telah membuktikan bahwa; pertama, Nabi Muhammad adalah pedagang sukses, hal ini karena kejujuran, keikhlasan serta integritas Nabi Muhamad dalam menjaga kualitas barang, dan konsumen. Selanjutnya dalam praktekpraktek transaksi jual beli beliau selalu menjunjung tinggi kemanusiaan dan tidak hanya berorientasi duniawi saja. Beliau selalu menjaga sifat jujur, ikhlas, profesional, silaturrahim dan murah hati dalam semua aktifitasnya terutama dalam bisnisnya. 


\section{DAFTAR PUSTAKA}

Akhmad Mujahidin, Etika Bisnis Dalam Islam (Analisis Terhadap Aspek Moralitas Pelaku Bisnis),Jurnal Hukum Islam. Vol. IV No. 2. Desember 2005.

Abdul Karim, Khalil, Syari'ah, Sejarah Perkelahian Pemaknaan, Yogyakarta: LKiS, 2003

Amirulloh Syarbini dan J. Haryadi,Muhammad Bisnisman Ulung, Jakarta: Elex Media Komputindo, 2011.

Gunara, Thorik dan Hardiono Sudibyo, utus, Marketing Muhammad SAW, .Bandung: Madania Prima, 2008.

http://pengusaharindusyariah.com/segmentasi-untuk-penetrasi-serial-mind-share$\underline{1 /}$

Ketut Rindjin, Etika Bisnis dan Implementasinya, Jakarta: PT Gramedia Pustaka Utama, 2008.

Kamaludin Laode dan M. Richmuslim, Aboza,Cerdas Bisnis Cara Rasulullah, Jakarta: Richmuslim Adikarya Bangsa, 2010.

Kartajaya, Hermawan, Hermawan Kartajaya On Targeting, seri 9 Elemen Marketing,Bandung:Mizan, 2006.

K. Hitti, Philip, History of The Arabs, Jakarta: PT Serambi Ilmu Semesta, 2010

Kartajaya, Hermawan, Positioning, Seri 9 Elemen Marketing, Bandung; Mizan, 2006.

Kartajaya, Hermawan Differentiation, The 9 Core Element Of Marketing Series, Bandung: Mizan, 2006.

MuhammadAfzalurrahman, Sebagai Seorang Pedagang, Jakarta: Yayasan Swarna Bhumy, 2000.

Muhammad Saifullah, Etika Bisnis Dalam Praktek Mal Bisnis Muhammad, .Jurnal Economica, vol.1/edisi I/November 2010.

Sonny Keraf, Etika Bisnis, Yogyakarta: Kanisius, 1998. 